\title{
Cytochemical studies of uterine and trophoblastic surface coats during blastocyst attachment in the ewe
}

\author{
M. Guillomot*, J.-E. Fléchon and Suzanne Wintenberger-Torres \\ Station Centrale de Physiologie Animale, INRA, 78350-Jouy-en-Josas, France
}

\begin{abstract}
Summary. A glycoprotein coat was demonstrated on the outer surface of both the uterine and trophoblastic cells using ruthenium red, cationized ferritin, concanavalin A-peroxidase and phosphotungstic acid in $\mathrm{HCl}$. No changes were observed on the uterine epithelial surface of cyclic or pregnant animals before or during blastocyst attachment (Day 15). However, the cytochemical reactions were different on the trophoblastic cells of blastocysts at Days 13 and 15, the ruthenium red and cationized ferritin sites of reaction and the concanavalin $\mathrm{A}$ receptors being more homogeneously distributed on the outer surface of Day-15 trophoblast. The phosphotungstic acid staining demonstrated a glycoprotein substance between the trophoblast and the uterine epithelium in adhesion areas by Day 18.

The results suggest that biochemical changes occur in the composition or distribution of the trophoblastic cell coat during the process of blastocyst attachment in the ewe.
\end{abstract}

\section{Introduction}

The process of blastocyst attachment to the endometrium necessarily involves interactions between the apical surfaces of trophoblastic and uterine luminal epithelial cells. Various studies have been carried out to determine ultrastructural and cytochemical changes on these cell surfaces at the time of implantation (for reviews see Schlafke \& Enders, 1975; Enders, 1976; Enders \& Schlafke, 1979).

Cellular adhesiveness involves the glycoconjugates of the cell membrane (Moscona, 1971; Oppenheimer, 1978; Debray, 1979) and the changes in glycoconjugate components of the uterine and the trophoblastic cell surface during the implantation period in rodents have been studied (Holmes \& Dickson, 1973; Pinsker \& Mintz, 1973; Nilsson, Lindqvist \& Ronquist, 1973; Enders \& Schlafke, 1974; Jenkinson \& Searle, 1977; Enders, Schlafke \& Welsh, 1980). Little is known about such modifications in ruminants. We have described ultrastructural surface changes of the uterine epithelium and of the trophoblast during the early adhesion stages in the ewe (Guillomot, Fléchon \& Wintenberger-Torres, 1981) and the present paper presents an ultracytochemical study of the surface coats of the uterine luminal epithelium and of the trophoblast cells before and during attachment of the blastocyst.

\section{Materials and Methods}

\section{Animals and collection stages}

Fifteen ewes (Préalpes du Sud) were used to provide material during early pregnancy. The occurrence of oestrus was checked daily with a vasectomized ram and the ewes were allowed to

* Present address: Centre de Recherche en Reproduction animale, Faculté de Médecine vétérinaire, Université de Montréal, C.P. 5000 Saint-Hyacinthe, Québec, Canada J2S 7C6. 
mate twice on the first day of oestrus (Day 0) and were slaughtered between Days 6 and 20 of pregnancy (1 on Day 6, 2 on Day 11, 2 on Day 12, 3 on Day 13,1 on Day 14, 3 on Day 15 and 1 on each of Days 17, 18 and 20). The genital tract was excised and, up to Day 14, the blastocysts were flushed from the uterine horns with phosphate-buffered saline, $\mathrm{pH} 7 \cdot 3$. At Day 15 and later, the blastocysts were left within the uterine horns. Five unmated ewes were also studied, one on each of Days 6,10,12,13 and 15 of the oestrous cycle. To remove as much luminal material as possible in both groups, saline was used again to flush the uterine horns thoroughly and to rinse the blastocysts three times (except for the ewes in which blastocysts remained in situ). Pieces of endometrium and trophoblast were sliced with a razor blade and processed by the following cytochemical techniques.

\section{Ruthenium red procedure}

This technique for demonstrating acidic residues of membrane glycoconjugates (Luft, 1971) was applied only to uterine epithelium at Day 15 of gestation. Ruthenium red (BDH Labs, Poole, Dorset, U.K.) was added to $1 \%$ glutaraldehyde in $0.15 \mathrm{M}$-cacodylate buffer, $\mathrm{pH} 7.3$, to a final concentration of $0.05 \%$. Pieces of tissue were immersed in this solution for $2 \mathrm{~h}$ at room temperature and then rinsed in $0.15 \mathrm{M}$-cacodylate buffer. The same concentration of ruthenium red was added to $1 \% \mathrm{OsO}_{4}$ in the same buffer and tissues were post-fixed for $3 \mathrm{~h}$. After a rinse in the buffer, samples were dehydrated in alcohol and embedded in Epon. Ultrathin sections were observed without additional staining.

\section{Cationized ferritin}

After initial fixation for $30-60 \mathrm{~min}$ in $1 \%$ glutaraldehyde in $0.15 \mathrm{M}$-cacodylate buffer, $\mathrm{pH}$ 7.3 , the tissues were washed for $1 \mathrm{~h}$ in the same buffer and incubated for $45 \mathrm{~min}$ in cationized ferritin (Miles-Yeda, Israel) at a concentration of $0.4 \mathrm{mg} / \mathrm{ml}$ buffer. Then the specimens were rinsed in three batches of buffer $\left(10 \mathrm{~min}\right.$ each), post-fixed in $1 \% \mathrm{OsO}_{4}$ in cacodylate buffer, dehydrated and embedded in Epon. Ultrathin sections were examined without counterstaining or after brief staining with uranyl acetate and lead citrate.

To control acidic group specificity of the cationized ferritin binding (Danon, Goldstein, Marikovsky \& Skutelsky, 1972), control tissues were preincubated for $1 \mathrm{~h}$ in poly-L-lysine (Sigma type III, St Louis, Missouri, U.S.A.) at a concentration of $0.2 \mathrm{mg} / \mathrm{ml}$ in cacodylate buffer. After rinsing in buffer, the samples were incubated in the same ferritin solution and processed as previously described.

\section{Enzyme treatments}

To determine which components were reacting with ruthenium red and cationized ferritin, tissues were incubated with enzymes as follows. After prefixation in $1 \%$ glutaraldehyde and a rinse in $0.15 \mathrm{M}$-cacodylate buffer for $1 \mathrm{~h}$, pieces of tissues were incubated in trypsin $(2 \mathrm{mg} / \mathrm{ml}$ : Sigma type III), pronase (1 mg/ml; Calbiochem, B grade, San Diego, California, U.S.A.) or in Vibrio cholerae neuraminidase $(200 \mathrm{U} / \mathrm{ml}$; Behringwerke, Marburg, Germany) diluted in the buffer. Incubations were for $1 \mathrm{~h}$ at $37^{\circ} \mathrm{C}$, in a moist atmosphere. Control tissue samples were incubated under the same conditions in the buffer alone. After a rinse in buffer, the specimens were processed as described above.

\section{Concanavalin A-peroxidase procedure}

This procedure examines the distribution of carbohydrate residues (Bernhard \& Avrameas, 1971); concanavalin A (Con A) binds specifically to $\alpha$-D-glycopyranosyl, $\alpha$-D-mannopyranosyl, $\beta$-D-fructopyranosyl residues and to oligosaccharide sequences containing these monomers (Goldstein \& Hayes, 1978; Baenziger \& Fiete, 1979). 
Tissues were fixed for 30-60 min in the aldehyde fixative in $0.15 \mathrm{M}$-cacodylate buffer. After rinsing for $1 \mathrm{~h}$ in the same buffer, samples were incubated for $30 \mathrm{~min}$ in Con A (Canavalia ensiformis, $\times 3$ crystallized; Miles-Yeda) at a concentration of $0.1 \mathrm{mg} / \mathrm{ml}$ in $0.15 \mathrm{M}$-cacodylate buffer. After rinsing for $30 \mathrm{~min}$ in the buffer, the tissues were incubated in horseradish peroxidase (Sigma, type VI) at a concentration of $0.05 \mathrm{mg} / \mathrm{ml}$ for $10 \mathrm{~min}$ at room temperature, thoroughly rinsed and incubated with diaminobenzidine- $\mathrm{H}_{2} \mathrm{O}_{2}$ medium for $5 \mathrm{~min}$ in the dark (Graham \& Karnovsky, 1966). Following an additional buffer rinse, the tissues were post-fixed in $1 \% \mathrm{OsO}_{4}$ in $0.15 \mathrm{M}$-cacodylate buffer, rinsed, dehydrated in alcohol and embedded in Epon. As a control for non-specific adsorption of Con A, samples were incubated similarly but with 0.1 M- $\alpha$-methyl-D-mannoside (Fluka AG, Buchs, Switzerland) added to the Con A solution. Additional specimens were incubated in peroxidase but without exposure to Con $\mathrm{A}$ as a control for non-specific adsorption of peroxidase. To test for the presence of endogenous peroxidase, the peroxidase incubation was omitted after Con A exposure.

\section{Phosphotungstic acid (PTA) staining at low pH}

This technique for demonstrating acidic glycoproteins (Rambourg, Neutra \& Leblond, 1966) was used only at Days 17 and 18 of gestation. After fixation in $1 \%$ glutaraldehyde in cacodylate buffer for $6 \mathrm{~h}$, tissues were rinsed in buffer and stored overnight at $4^{\circ} \mathrm{C}$. After that, pieces of endometrium with attached trophoblast were dehydrated and embedded in glycol methacrylate which was then polymerized at $4^{\circ} \mathrm{C}$ under u.v. light for $24 \mathrm{~h}$. Ultrathin sections were placed on copper grids coated with a formvar film. The grids and sections were floated for $10 \mathrm{sec}$ on a $1.0 \mathrm{~N}-\mathrm{HCl}$ solution, stained for $45 \mathrm{sec}$ on a drop of $0.5 \%$ PTA (Prolabo, Paris, France) dissolved in $1.0 \mathrm{~N}-\mathrm{HCl}(\mathrm{pH}<0.2)$ and dried directly on a filter paper (Fléchon, 1979). Sections were examined without further counterstaining.

All electron micrographs were taken on a Zeiss EM10 electron microscope.

\section{Results}

\section{Uterine epithelium}

A surface coat on the apical surface of the uterine epithelial cells was demonstrated by all the cytochemical techniques used. No differences could be observed in the nature of the coat whichever stage of the cycle or of pregnancy or whichever endometrial area (caruncular or intercaruncular) was examined.

Ruthenium red produced an electron-dense deposit on the outer surface of the uterine epithelium at Day 15 of gestation. The reactive material was uniformly distributed along the luminal plasma membrane of the uterine cells. No differences in staining were observed between the microvilli and the cytoplasmic apical protrusions which are numerous at this stage. The dye did not penetrate the apical junctional complex between the cells (Pl. 1, Fig. 1). Some damaged uterine cells allowed access of the stain complex to the cytoplasm. The electron-dense deposit was not observed after incubation of tissues with the trypsin solution (Pl. 1, Fig. 2) but remained apparent after their treatment with neuraminidase or poly-L-lysine.

In all samples examined, the presence of negatively charged groups within the surface coat was clearly demonstrated by the cationized ferritin technique. Ferritin particles were uniformly distributed and formed a thin layer on the outer surface of the uterine cells (Pl. 1, Figs 3 and 4). The adsorption of the ferritin was inhibited by a preincubation of the tissues in the presence of poly-L-lysine (Pl. 1, Fig. 5), confirming that ferritin binding was to negative groups. After trypsin treatment the reaction was decreased, leaving only clusters of ferritin along the cellular membrane (Pl. 1, Fig. 6). However, no reduction of binding was seen after the neuraminidase treatment. 
At all stages examined, the final reaction products of the Con A-peroxidase procedure formed a thick layer on the entire apical surfaces of the uterine epithelial cells and stopped at the apical junctional complexes (Pl. 2, Figs 7-9). After incubation of the tissues in the presence of $0.1 \mathrm{M}-\alpha$-methyl-D-mannoside the reaction was inhibited (Pl. 2, Fig. 10). No reaction product was observed on samples incubated without Con A, thus giving evidence of non-adsorption of peroxidase per se. Neither was the reaction product observed in tissues which had not been incubated with the peroxidase solution after the Con $\mathrm{A}$ incubation.

\section{PLATE 1}

Sheep uterine tissues treated with the ruthenium red and cationized ferritin techniques.

Fig. 1. Uterine cell surface stained by the ruthenium red procedure (Day 15 of gestation). The electron-dense reaction outlines the whole cell surface but no electron-dense material penetrates the apical junctional complex (j). $\times 8200$.

Fig. 2. Control tissue incubated with trypsin (Day 15 of gestation) before ruthenium red exposure. No electron-dense material is observed on the surface. $\times 28000$.

Fig. 3. Uterine epithelium incubated with cationized ferritin (Day 13 of gestation). The ferritin particles outline the cell surface and the microvilli. Some extracellular material binds more ferritin (arrow). $\times 43000$.

Fig. 4. Uterine epithelium incubation with cationized ferritin (Day 15 of gestation). Ferritin distribution is similar to that seen in Fig. 3. $\times 47000$.

Fig. 5. Uterine epithelium incubated with poly-L-lysine before incubation with cationized ferritin (Day 15 of gestation). Ferritin binding is greatly reduced. $\times 40000$.

Fig. 6. Uterine epithelium incubated with trypsin before incubation with cationized ferritin (Day 15 of gestation). Ferritin binding is slightly reduced and clusters of particles are more numerous (compare with Fig. 4). $\times 41000$.

\section{PLATE 2}

Sheep uterine tissues treated with the Concanavalin A-peroxidase technique.

Fig. 7. Uterine epithelium at Day 13 of gestation. The electron-dense reaction product uniformly covers the microvillar surface and stops at the apical junctional complex (j). $\times 14000$.

Fig. 8. Uterine epithelium at Day 15 of gestation. The reaction product is present both on the outer surface of the microvilli and the apical membrane of a cytoplasmic extrusion. $\times 14000$.

Fig. 9. Uterine epithelium at Day 6 of the oestrous cycle. No difference in staining is observed when compared with Figs 7 and $8, \times 28000$.

Fig. 10. Control tissue incubated in the presence of $0.1 \mathrm{M}-\alpha$-methyl-D-mannoside added to the Con A solution. Note the complete inhibition of the staining reaction. $\times 16000$.

\section{PLATE 3}

Blastocyst tissues stained with ruthenium red.

Fig. 11. At Day 13, the electron-dense material is observed only in invaginations of the plasma membrane (arrows). The outer surfaces of the microvilli are scarcely stained. $\times 20000$.

Fig. 12. At Day 15 the ruthenium red reaction product is uniformly distributed on the outer cell surface of the trophoblast in the intercellular space but stops at the apical junctional complex (j). $\times 20000$.

Fig. 13. An apical cleft at Day 13 (the outside of the blastocyst is beyond the top of the photograph) showing the endocytotic invaginations (arrows) containing electron-dense material. No reaction product is present beneath the apical junctional complex $(j) . \times 26000$.

Fig. 14. At the basal pole of trophoblastic cells on Day 13, a filamentous electron-dense material is stained by the ruthenium red on the basal lamina and in the intercellular space. $\mathrm{BC}=$ blastocoele. $\times 32000$. 
PLATE 1
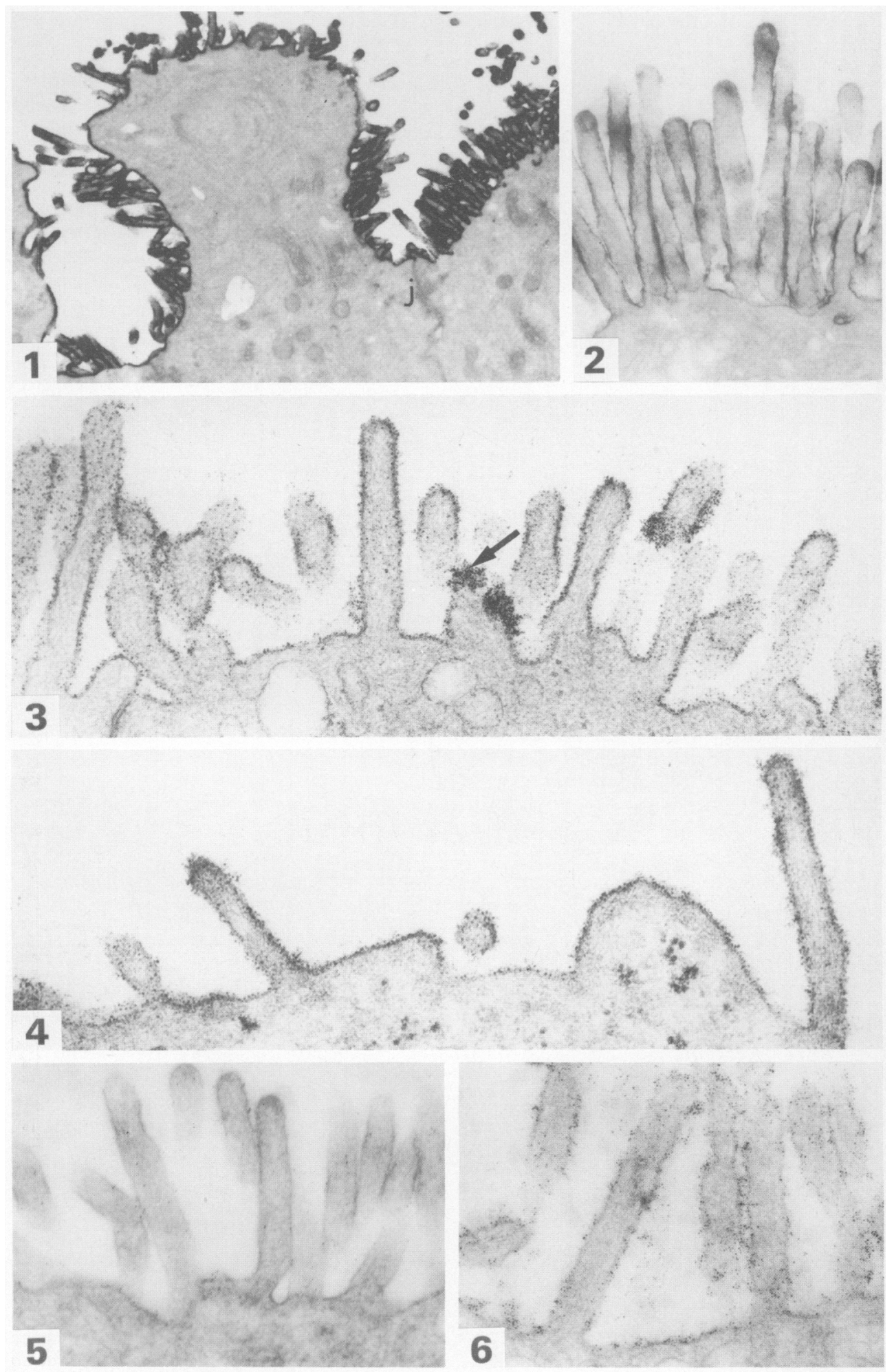

(Facing p. 4) 
PLATE 2
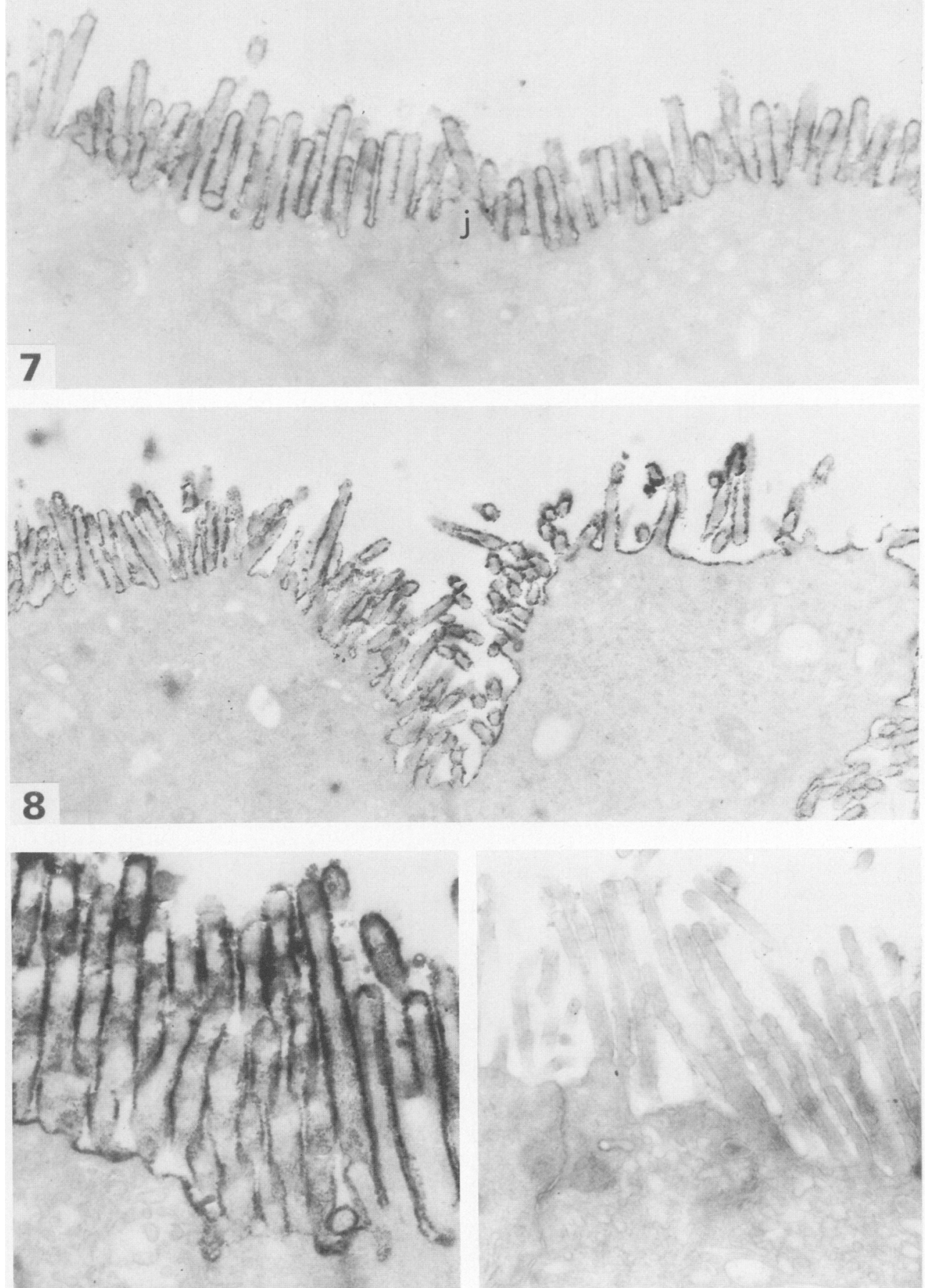

9

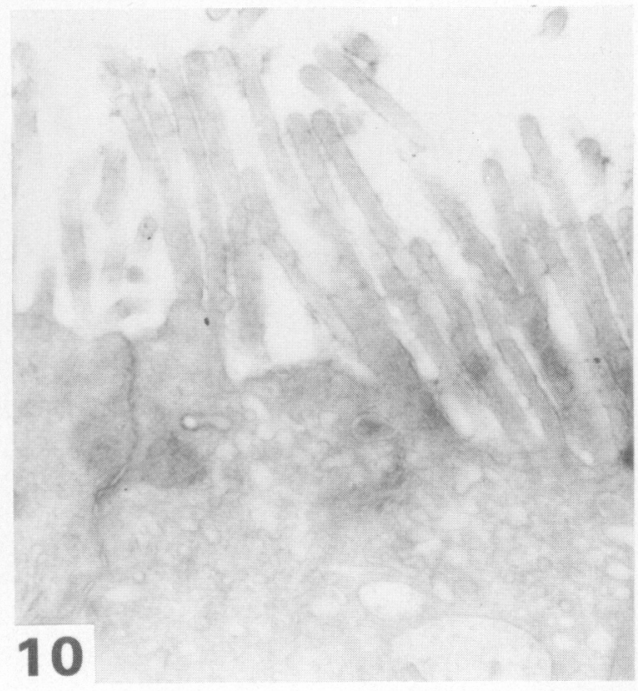




\section{PLATE 3}
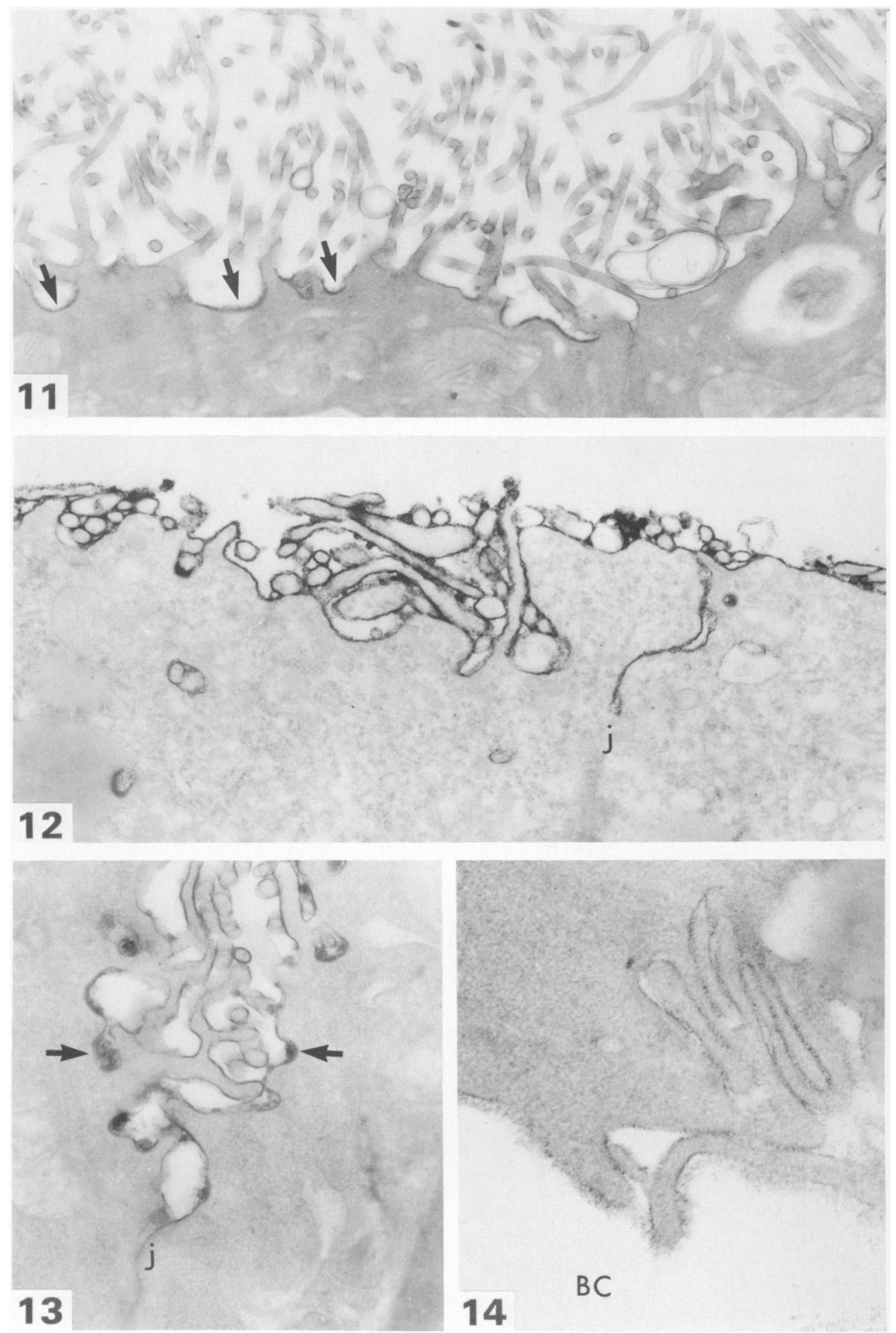
PLATE 4
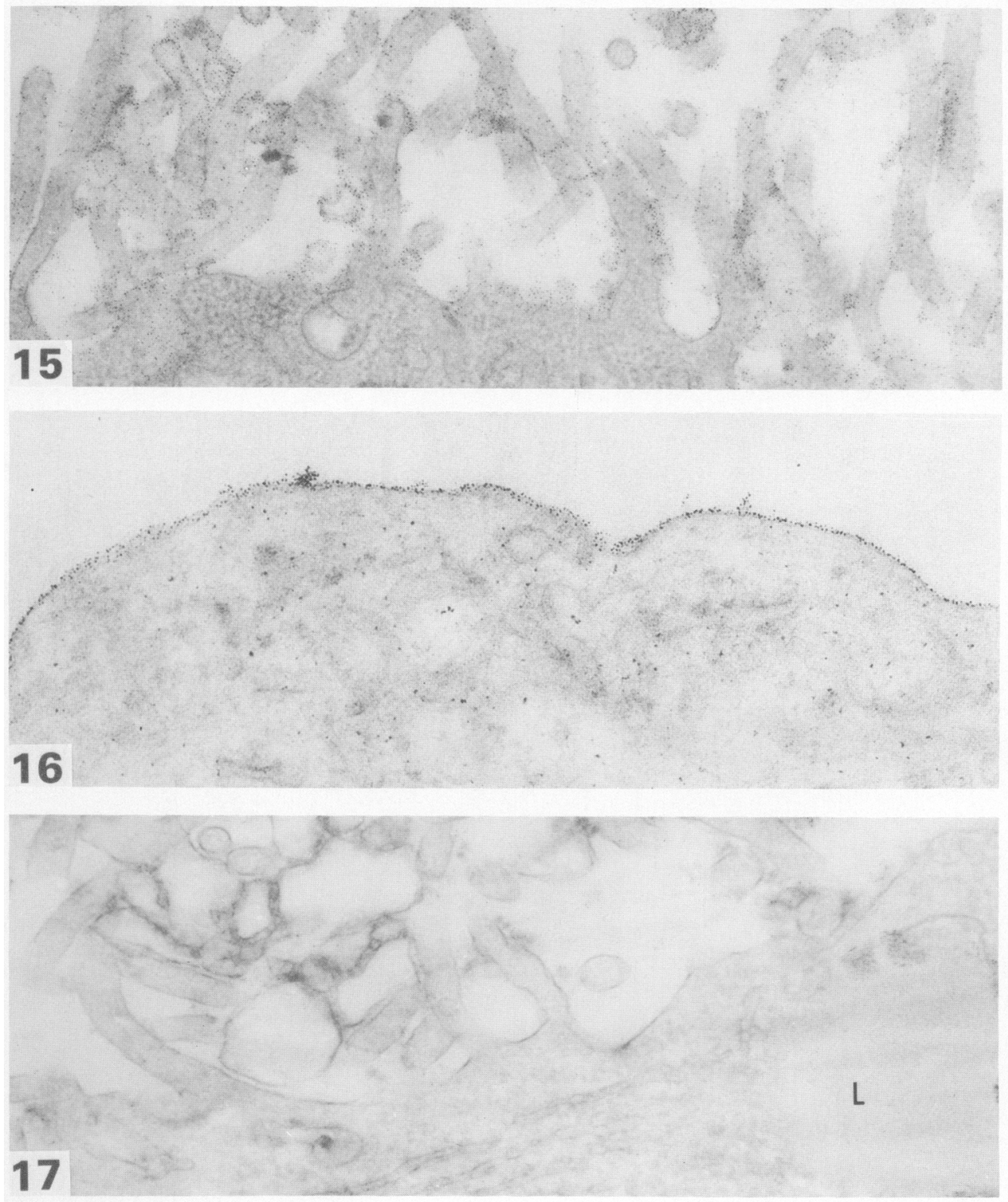
PLATE 5
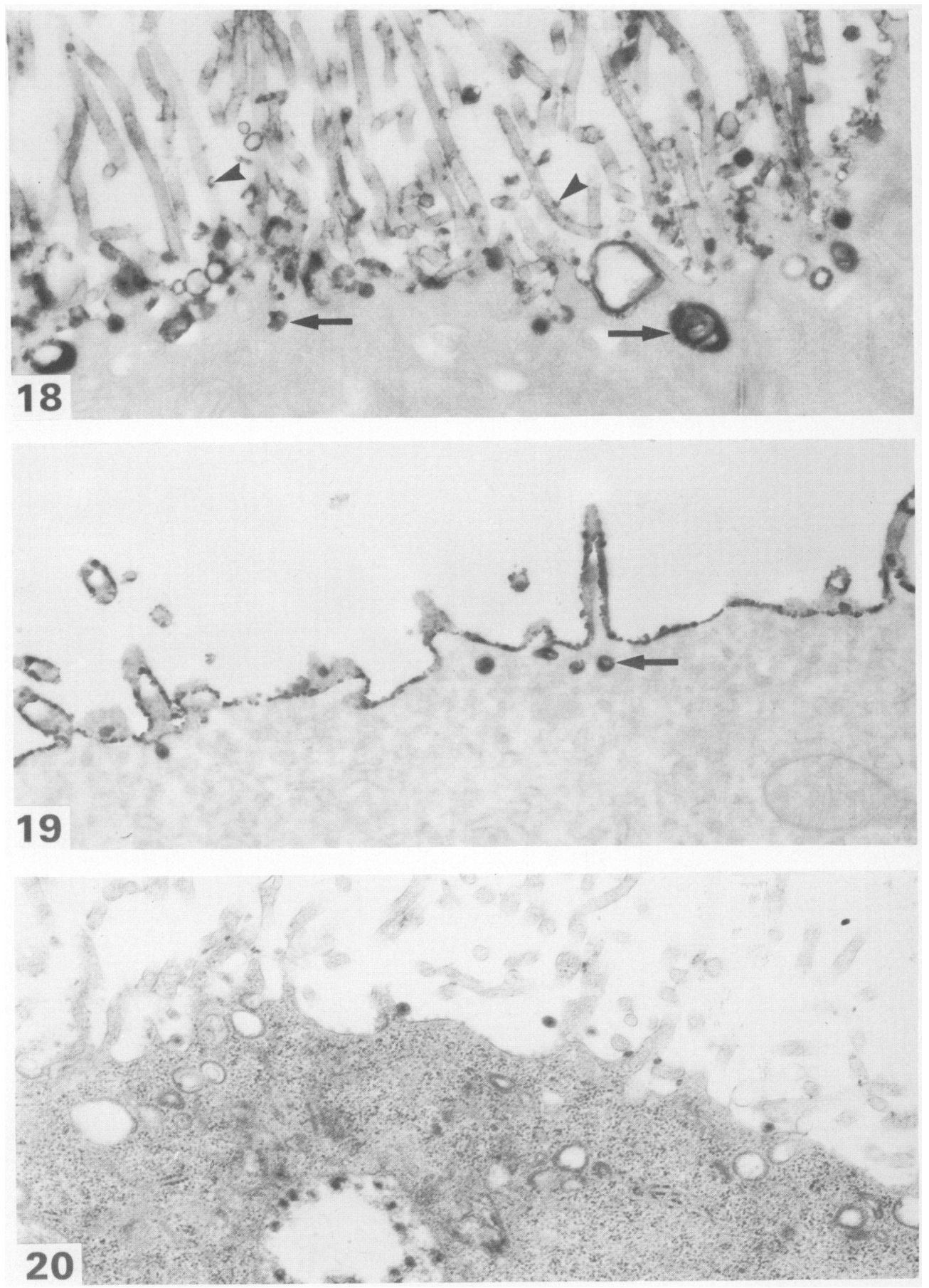

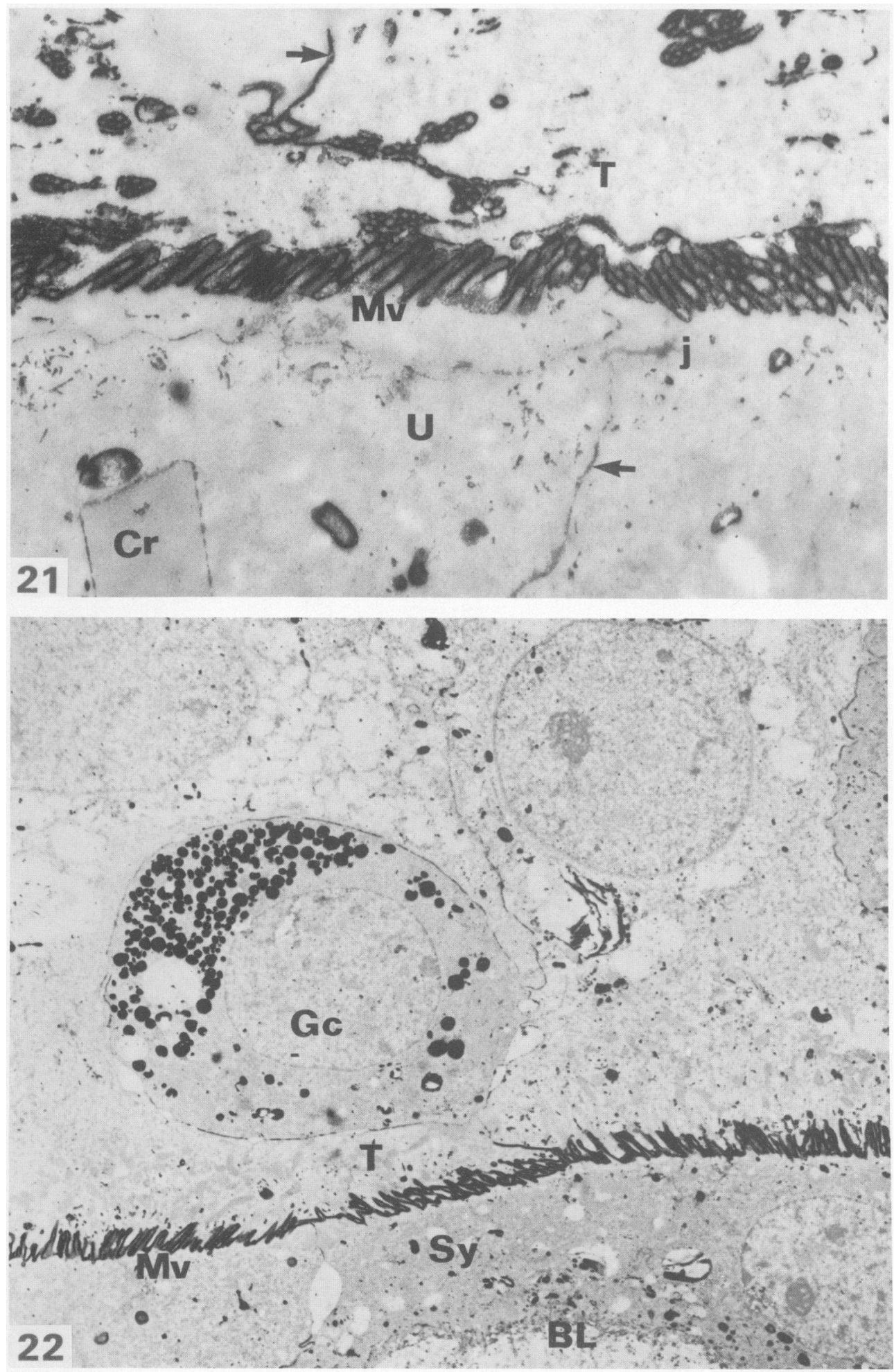


\section{Trophoblast}

With the ruthenium red procedure some differences in staining were observed depending on the stage studied. At Day 13, patches of electron-dense deposit were observed on the outer surface of the numerous microvilli. Beneath the microvilli, the apical membrane showed electron-dense material only in invaginations which were probably involved in endocytotic processes (Pl. 3, Fig. 11). In contrast, in conceptuses at Day 15 the extracellular deposit was homogeneously distributed on the apical surface projections of the trophoblastic cells (Pl. 3, Fig. 12). At both stages the reaction product stopped abruptly at the junctional complex (Pl. 3, Fig. 13). The ruthenium red reaction with extracellular material at the basal poles of some cells (Pl. 3, Fig. 14) could be attributed to the use of conceptuses that had been cut into pieces during preparation. The reaction product was also present on the surface of endodermal cells.

Cationized ferritin bound unevenly to the outer surfaces of the trophoblastic cells at Days 11 and 13 of gestation, with particles appearing in clusters rather than isolated (Pl. 4, Fig. 15). After Day 14, the ferritin particles were uniformly distributed on the outer smooth surface of the trophoblastic cells (Pl. 4, Fig. 16). In all samples, the ferritin binding was inhibited by

\section{PLATE 4}

Blastocyst tissues treated with cationized ferritin.

Fig. 15. At Day 13, there is uneven distribution of ferritin particles on the outer surface of the microvilli and the plasma membrane. $\times 40000$.

Fig. 16. At Day 15, the trophoblast cell surface is smooth and devoid of microvilli and there is homogeneous binding of ferritin particles. $\times 40000$.

Fig. 17. Control tissue (Day 14) preincubated with poly-L-lysine before exposure to cationized ferritin. Note the disappearance of ferritin binding on the cellular membrane. $L=$ lipid inclusion. $\times 40000$.

\section{PLATE 5}

Blastocyst tissues treated with the Concanavalin A-peroxidase technique.

Fig. 18. At Day 13, the electron-dense reaction product occurs mainly inside endocytotic invaginations (arrows) of the trophoblastic cell membrane. Only a few electron-dense clusters (arrow heads) are present on the outer surface of the microvilli. $\times 20000$.

Fig. 19. At Day 15, the electron-dense deposit covers the whole trophoblast cell surface. Note that the microvilli are reduced in length and number. Endocytotic invaginations also contain electron-dense material (arrow). $\times 20000$.

Fig. 20. Control tissue (Day 13) incubated with $0 \cdot 1 \mathrm{M}-\alpha$-methyl-D-mannoside added to the Con A solution. No reaction product is present on the cellular membrane. $\times 20000$.

\section{PLATE 6}

Uterine and blastocyst tissues after phosphotungstic acid- $\mathrm{HCl}$ staining.

Fig. 21. At the apposition stage at Day 17 of gestation, a PTA-positive material is present on the uterine microvilli $(\mathrm{Mv})$ and on the membrane of the trophoblastic cell $(\mathrm{T})$ apposed to the uterine epithelium (U). The electron-dense material is also observed in the intercellular space (arrow) and the trophoblastic apical cleft (arrow) but is absent at the apical tight junctions (j). Endocytotic (or secretory) vesicles are also stained and the matrix of crystalline inclusions $(\mathrm{Cr})$ is surrounded by stained material. $\times 13500$.

Fig. 22. At the adhesion stage at Day 18 of gestation, the PTA-positive material is present between the indented membrane of the trophoblastic cell $(\mathrm{T})$ and the microvilli $(\mathrm{Mv})$ of the uterine syncytium (Sy). A trophoblastic giant cell $(\mathrm{Gc})$ is present among the mononucleated trophoblastic cells. These giant cells are not in contact with the uterine syncytium. In both tissues cytoplasmic granules are stained by the PTA. The uterine basal lamina (BL) is also stained. $\times 4000$. 
preincubation in poly-L-lysine solution (PI. 4, Fig. 17). After trypsin or neuraminidase treatment, the reaction was reduced but not completely abolished.

On the trophoblastic cells of Day-13 blastocysts, the final reaction product of the Con A-peroxidase procedure was observed chiefly in invaginations at the base of the microvilli and only in patches on the surfaces of microvilli. The reaction product did not penetrate the apical junctional complexes (PI. 5, Fig. 18). At Day 15 of gestation, the Con A-peroxidase procedure gave an electron-dense deposit uniformly distributed on the apical smooth membrane and along short microvilli remaining on the cellular surface (PI. 5, Fig. 19). The reaction product was still present at Day 20 of gestation. When the tissues were incubated in the presence of 0.1 M- $\alpha$-methyl-D-mannoside, the Con A binding was inhibited (Pl. 5, Fig. 20). It was also absent if the Con $\mathrm{A}$ or peroxidase incubations were omitted.

\section{Uterine-trophoblast interface}

The PTA $/ \mathrm{HCl}$ staining was particularly useful to demonstrate an extracellular material between the uterine epithelium and the trophoblast at the contact areas. This was not possible with the other methods described above.

By Day 17, the undulating smooth membrane of the trophoblast cells in some areas was closely apposed to the tips of the uterine microvilli (apposition stage). A PTA-positive material was observed filling the space between the two epithelia. The staining stopped at the apical junctional complex. In both tissues cytoplasmic endocytotic vesicles and crystalline inclusions were surrounded by stained material (Pl. 6, Fig. 21).

In adhesion areas at Day 18, the PTA-positive material was still present at the intervillous junction between the two tissues. At this stage, binucleated cells were observed among mononucleated trophoblastic cells. Both tissues contained PTA-positive granules (Pl. 6, Fig. 22). The Golgi vesicles and the basal lamina of the maternal syncytium were also demonstrated by the PTA/HCl staining. If the uterine epithelium and the trophoblast separated during processing, the PTA staining was present on the apical membranes of both tissues.

\section{Discussion}

A cell coat was clearly demonstrated on the surface of the uterine epithelium and the trophoblast. Its chemical nature is probably complex and the methods used here revealed only some of its components.

Anionic sites were demonstrated by binding of cationized ferritin and the ruthenium red staining. Since the cationized ferritin has a high molecular weight $(445000)$ only the outermost acidic groups are bound and probably only those present on the cell coat material rather than those intrinsic to the plasma membrane. In our study the reactions were carried out at $\mathrm{pH} 7 \cdot 3$, so numerous acidic residues were ionized and could react with the cationized ferritin. This could explain the incomplete inhibition of the reaction after incubation of the tissues with a neuraminidase solution because acidic groups with a higher $\mathrm{pK}$ than the sialic acid released by this enzyme would have still been able to bind the ferritin (De Bruyn, Michelson \& Becker, 1978). Furthermore, the aldehyde prefixation may have induced alterations in the distribution of the membrane anionic sites (Grinnell, Anderson \& Hackenbrock, 1976) and the sialic acid release by the neuraminidase (Nelson, Smith, Enders \& Donohue, 1976). In addition, treatment by proteolytic enzymes and neuraminidase could unmask deeper anionic sites that could then be bound by the marker. These remarks apply equally to the results obtained by the ruthenium red procedure. In this case, however, trypsin digestion demonstrated the protein nature of the cell coat material. The binding of Con A revealed the presence of large amounts of carbohydrate residues on the uterine and trophoblastic cell surfaces in the ewe. Although the specificity of the PTA staining has been questioned (Holt, 1979), there is evidence that the staining is selective for glycoprotein (Fujioka \& Ogawa, 1979). Furthermore, the PTA-positive 
material that we observed between the trophoblastic and uterine surfaces is similar to the PAS-positive material observed on histological sections during early attachment stage in the ewe (Boshier, 1969).

Our study did not show any changes in the nature and distribution of the uterine cell coat material either during the oestrous cycle or in relation to the attachment process. This is in agreement with histochemical studies of the bovine endometrium (Wordinger \& Amsler, 1980) and comparative biochemical analysis of a plasma membrane-enriched fraction of the pig uterus during the oestrous cycle and early pregnancy (Mullins, Horst, Bazer \& Roberts, 1980). However, the possibility that some subtle changes do occur, undetected by all the techniques used, cannot be excluded. Using an in-vitro and in-vivo cationized ferritin labelling of unfixed uterus, Hewitt, Beer \& Grinnell (1979) have shown that all ionic sites disappear from the uterine cell surface at implantation in the rat. This may be related to the different type of implantation in that species.

As far as the ovine blastocyst is concerned, the results obtained here demonstrate that some changes of the cell coat first appear at Day 15, coincident with the beginning of attachment and morphological modifications of the trophoblast cell surface (Fléchon, Guillomot \& Wintenberger-Torrès, 1978). At this stage, the coat's reactions with ruthenium red, cationized ferritin and Con A all increased on the plasma membrane. At Day 13 the stained material was observed beneath the microvilli in invaginations of the plasma membrane, suggesting the presence of selective endocytotic sites of an extracellular material previously bound on the cellular membrane. The chemical composition of a molecule as well as its net charge (Farquhar, 1978) appear to be involved in the endocytotic processes. The fact that the reaction products were present mainly in the deep portion of the apical membrane indicates that the microvilli did not reduce the access of the markers to the cell coat. Therefore, the increased staining reaction demonstrated at Day 15 was not due solely to the loss of microvilli observed at this stage. These cell coat changes could result from a de-novo synthesis of new components and/or the unmasking of hidden sites by proteolytic enzymes present in the uterine secretions as suggested in the mouse (Pinsker, Sacco \& Mintz, 1974; Hoversland \& Weitlauf, 1981) and in the rabbit (Denker, 1977). However, in-vitro studies in the mouse have shown that the blastocyst becomes adhesive in the absence of any uterine factors, so the adhesive factors may be of embryonic origin (Sherman \& Atienza-Samols, 1978). It is not clear what role the surface coats play in blastocyst attachment. To date, no complete molecular mechanism of adhesion between the blastocyst and the uterine epithelium has been advanced but it is unlikely that this phenomenon is a simple matter of surface charge because in the ewe both blastocyst and uterine epithelium react similarly with ruthenium red and cationized ferritin. The implied electro-negative charges on the two surfaces would therefore tend to be mutually repellent.

In addition to an adhesive role, the surface coat of the blastocyst could act as a trophoblastic immunological barrier against immune response of the maternal organism (Bradbury, Billington, Kirby \& Williams, 1970). Our understanding of any such role will require further studies.

We are grateful to Ms C. Rebours for skilful assistance in collecting samples, to Ms D. Théberge for typing and to Dr K. Betteridge for his help with the English of the manuscript. This work was supported by a grant from the Délégation Générale à la Recherche Scientifique et Technique, Paris, awarded to M.G.

\section{References}

Baenziger, J.U. \& Fiete, D. (1979) Structural determinants of Concanavalin A specificity for oligosaccharides. J. Biol. Chem. 254, 2400-2407.

Bernhard, W. \& Avrameas, S. (1971) Ultrastructural visualization of cellular carbohydrate components by means of Concanavalin A. Expl Cell Res. 64, 233-236.

Boshier, D.P. (1969) An histological and histochemical examination of implantation and early formation in sheep. J. Reprod. Fert. 19, 51-61.

Downloaded from Bioscientifica.com at 04/26/2023 12:38:05PM 
Bradbury, S., Billington, W.D., Kirby, D.R.S. \& Williams, E.A. (1970) Histochemical characterization of the surface mucoprotein of normal and abnormal human trophoblast. Histochem. J. 2, 263-274.

Danon, D., Goldstein, L., Marikovsky, Y. \& Skutelsky, E. (1972) Use of cationized ferritin as a label of negative charges on cell surfaces. J. Ultrastruct. Res. $38,500-510$.

Debray, H. (1979) Les glycoconjugués de la membrane de surface des cellules normales et cancéreuses. Bull. Cancer (Paris) 66, 353-372.

De Bruyn, P.P.H., Michelson, S. \& Becker, R.P. (1978) Non-random distribution of sialic acid over the cell surface of bristle-coated endocytotic vesicles of the sinusoidal endothelial cells. J. Cell Biol. 78, 379-384.

Denker, H.W. (1977) Implantation. The role of proteinases and blockage of implantation by proteinase inhibitors. Adv. Anat. Embryol. Cell Biol. 53, 1-123.

Enders, A.C. (1976) Anatomical aspects of implantation. J. Reprod. Fert. Suppl. 25, 1-15.

Enders, A.C. \& Schlafke, S. (1974) Surface coats of the mouse blastocyst and uterus during the preimplantation period. Anat. Rec. 180, 31-46.

Enders, A.C. \& Schlafke, S. (1979) Comparative aspects of blastocyst-endometrial interactions at implantation. In Maternal Recognition of Pregnancy (Ciba Fdn Symp. No. 64), pp. 3-32. Excerpta Medica, Amsterdam.

Enders, A.C., Schlafke, S. \& Welsh, A.O. (1980) Trophoblastic and uterine luminal epithelial surfaces at the time of blastocyst adhesion in the rat. $A m . J$. Anat. 159, 59-72.

Farquhar, M.G. (1978) Recovery of surface membrane in anterior pituitary cells. Variations in traffic detected with anionic and cationic ferritin. J. Cell Biol. 77, R35-R42.

Fléchon, J.-E. (1979) Sperm glycoproteins of the boar, bull, rabbit and ram. I. Acrosomal glycoproteins. Gamete Res. 2, 43-51.

Fléchon, J.-E., Guillomot, M. \& Wintenberger-Torrès, S. (1978) Etude ultrastructurale du blastocyste et de l'implantation chez la brebis. In Implantation de l'Oeuf, pp. 107-119. Eds F. du Mesnil du Buisson, A. Psychoyos \& K. Thomas. Masson, Paris.

Fujioka, A. \& Ogawa, K. (1979) Ultracytochemistry of the membrane. II. The application of phosphotungstic acid staining to microvillus membranes of the cat small intestine. Acta histochem. cytochem. 12, 97-119.

Goldstein, I.J. \& Hayes, C.E. (1978) The lectins: carbohydrate-binding proteins of plants and animals. Adv. Carbohydr. Chem. Biochem. 35, 127-340.

Graham, R.C., Jr \& Karnovsky, M.J. (1966) The early stages of absorption of injected horseradish peroxidase in the proximal tube of mouse kidney; ultrastructural cytochemistry by a new technique. $J$. Histochem. Cytochem. 14, 291-302.

Grinnell, F., Anderson, R.G.W. \& Hackenbrock, K. (1976) Glutaraldehyde-induced alterations of membrane anionic sites. Biochim. Biophys. Acta 426, 772-775.

Guillomot, M., Fléchon, J.-E. \& Wintenberger-Torrès, S. (1981) Conceptus attachment in the ewe: an ultrastructural study. Placenta 2, 169-182.
Hewitt, K., Beer, A.E. \& Grinnell, F. (1979) Disappearance of anionic sites from the surface of the rat endometrial epithelium at the time of blastocyst implantation. Biol. Reprod. 21, 691-707.

Holmes, P.J. \& Dickson, A.D. (1973) Estrogen-induced surface coat and enzyme changes in the implanting mouse blastocyst. J. Embryol. exp. Morph. 29, $639-645$.

Holt, W.V. (1979) Development and maturation of the mammalian acrosome. A cytochemical study using phosphotungstic acid staining. J. Ultrastruct. Res. $68,58-71$.

Hoversland, R.C. \& Weitlauf, H.M. (1981) Lysis of the zona pellucida and attachment of embryos to the uterine epithelium in ovariectomized mice treated with oestradiol-17 $\beta$ and progesterone. J. Reprod. Fert. 62, 111-116.

Jenkinson, EJ. \& Searle, R.F. (1977) Cell surface changes on the mouse blastocyst at implantation. Expl Cell Res. 106, 386-390.

Luft, J.H. (1971) Ruthenium red and violet. I. Chemistry, purification, methods of use for electron microscopy and mechanism of action. Anat. Rec. 171, 347-368.

Moscona, A.A. (1971) Embryonic and neoplastic cell surfaces: availability of receptors for Concanavalin A and wheat germ agglutinin. Science, N.Y. 171, 905-907.

Mullins, D.E., Horst, M.N., Bazer, F.W. \& Roberts, R.M. (1980) Isolation and characterization of a plasma membrane fraction derived from the luminal surface of the pig uterus during the estrous cycle and early pregnancy. Biol. Reprod. 22, 1181-1192.

Nelson, D.M., Smith, C.H., Enders, A.C. \& Donohue, T.M. (1976) The non-uniform distribution of acidic components of the human placental syncytial trophoblast surface membrane: a cytochemical and analytical study. Anat. Rec. 184, 159-181.

Nilsson, O., Lindqvist, I. \& Ronquist, G. (1973) Decreased surface charge of mouse blastocyst at implantation. Expl Cell Res. 83, 421-423.

Oppenheimer, S.B. (1978) Cell surface carbohydrates in adhesion and migration. Am. Zool. 18, 13-23.

Pinsker, M.C. \& Mintz, B. (1973) Change in cell-surface glycoproteins of mouse embryos before implantation. Proc. natn. Acad. Sci., U.S.A. 70, 1645-1648.

Pinsker, M.C., Sacco, A.G. \& Mintz, B. (1974) Implantation-associated proteinase in mouse uterine fluid. Devl Biol. 38, 285-290.

Rambourg, A., Neutra, M. \& Leblond, C.P. (1966) Presence of a "cell coat" rich in carbohydrates at the surface of cells in the rat. Anat. Rec. 154, 41-72.

Schlafke, S. \& Enders, A.C. (1975) Cellular basis of interaction between trophoblast and uterus at implantation. Biol. Reprod. 12, 41-65.

Sherman, M.I. \& Atienza-Samols, S. B. (1978) In vitro studies on the surface adhesiveness of mouse blastocyst. In Human Fertilization, pp. 179-183. Eds H. Ludwig \& P. F. Tauber. Springer-Verlag, Berlin.

Wordinger, R.J. \& Amsler, K.R. (1980) Histochemical identification of the glycocalyx layer in the bovine oviduct and endometrium. Anim. Reprod. Sci. 3, 189-193. 